\title{
Cause of Death in Carbonized Children: What is The Role of Carboxyhemoglobin?
}

\author{
Keywords \\ Death \\ Child; Charred corpses; Carboxyhemoglobin; Autopsy; Manner of
}

\begin{abstract}
While fire-related deaths are regularly encountered by medical examiners and in the forensic practice, one of the most important signs that death occurred by carbon monoxide poisoning is the blood level of Carboxyhemoglobin, which usually is stated by the literature as above $50 \%$. We examined retrospectively the reports of 16 children charred corpses that died in closed space. The dosage of Carboxyhemoglobin of 10 of them was less than $50 \%$. In absence of any other plausible manner of death, the examiners concluded that the cause of death was due to carbon monoxide poisoning. The authors emphasize the necessity of further research to establish adequately what is the lethal blood level of carboxyhemoglobin in children.
\end{abstract}

\section{Introduction}

The World Health Organization estimated that 265,000 deaths occurred every year caused by burns1. When a body is recovered from the scene of a fire, from the forensic point of view, is important to determine the manner of death. As stated by Melez et al [1], "a multidisciplinary approach is crucial to uncover the manner of death."In forensic practice, bodies of unknown persons or carbonized corpses have to be formally identified. In the local scene of a fire, is crucial to the forensic agent to identify if the bodies he found were victims of the fire if they were already dead, or victim of homicide, for example. The majorityof all fire deaths are due to smoke and soot inhalation. The most common toxic agent in this condition is carboxyhemoglobin ( $\mathrm{COHb}$ ), whose levels above $40 \%$ to $60 \%$ are frequently cited as fatal [2]. Besides, fire-related deaths may also occur due to other causes as sequelae of thermal injuries, antecedent trauma, or even homicide. As pointed by Dolinak, Matshes, and Lew [3], "death may ensue because of the burns themselves, smoke inhalation, or some combination of the two." Thus to determine the cause of death it must first be established whether the victim was alive at the time of the fire and what caused the death, insofar as burning the body may be an attempt to hide the traces of the real cause of death, as in homicides by firearms or the use of blunt instruments. At this point, two things are important and relevant as evidence that the person was alive at the time of the fire: soot lining the airways (Montalti sign) and an elevated blood carboxyhemoglobin saturation.

The purpose of toxicology is the study of toxic agents, such as drugs and pharmaceuticals, and their relationship with living organisms, causing everything from minor functional changes to death. Forensic toxicology thus encompasses essential techniques to prepare evidence for criminal investigations. As we said, one of the problems to be solved in medico-legal necropsy that require the help of forensic toxicology in fire victims involves primarily the following
Journal of

Forensic

Investigation

\author{
Miziara ID ${ }^{1 *}$ and Miziara CSMG ${ }^{2}$ \\ ${ }^{1}$ Department of Legal Medicine, Ethics, Social and Occupational \\ Health, São Paulo University Brazil \\ ${ }^{2}$ Discipline of Legal Medicine, ABC School of Medicine,Santo André, \\ Brazil.
}

\section{*Address for Correspondence}

Mziara ID, Associate Professor, Head of Department of Legal Medicine, Ethics, Social and Occupational Health, São Paulo University Faculty of Medicine, São Paulo-Brazil; Email: Ivan.miziara@usp.br

Submission: 19 May, 2021

Accepted: 20 June, 2021

Published: 25 June, 2021

Copyright: (๑ 2021 Miziara ID, et al. This is an open access article distributed under the Creative Commons Attribution License, which permits unrestricted use, distribution, and reproduction in any medium, provided the original work is properly cited.

objectives: determination of the cause of death, that is whether the death was due to the effects of the burns suffered by the victim, or if the death was the result of inhaling a lethal dose carbon monoxide (with the subsequent formation of carboxyhemoglobin at levels incompatible with life). In children's charred corpses, there is an additional problem: there are not many studies that could answer the question: what is the lethal level of $\mathrm{COHb}$ in children?

According to Spitz "even low levels of carboxyhemoglobin are significant. A few breaths suffice to accumulate a meaningful concentration." [4]. It is important to note that while the presence of $\mathrm{COHb}$ is proof of life when the fire started, its absence does not imply that death occurred before the fire.

Absence and low concentrations can appear in situations such as flash fires, conflagration in a chemical plant, in warfare or explosion, when death may be instantaneous. Most of these deaths are not caused by burns, but, as stated by Saukko and Knight, by inhalation of fumes produced by the combustion of building structure and contents. Carbon monoxide poisoning is an important aspect of most fires - "indeed it is the major or even sole cause of death in many victims of conflagrations, especially in house fires" [5].

Otherwise, according to forensic literature, levels of $\mathrm{COHb}$ in the blood greater than $50 \%$ confirm death from CO poisoning, concentrations between $10 \%$ and $50 \%$ indicate that the victim could have been alive when the fire started, and concentrations below $10 \%$ indicate that the victim was probably dead when the fire started [6].

Older individuals and those with significant medical disease (in particular, heart disease) will have less physiological reserve and may succumb to lower levels of $\mathrm{COHb}$ saturation - sometimes even at levels as low as 20 percent [1].

Besides, it is important to point out that children have physiological differences relative to adults, such as lower blood volume, faster basal metabolism (which requires greater tissue 
oxygenation), and greater pulmonary ventilation $[6,7]$ and therefore lethal levels of $\mathrm{COHb}$ in children may be lower than those found in adults. Although the toxic levels reported in the literature for $\mathrm{COHb}$ ranged between $25 \%$ and $85 \%$ [8s] there are no standardized values in the forensic literature for measuring $\mathrm{COHb}$ in children who are victims of the fire. This aspect can become a major problem when we examine the body of a charred child. Precisely for that reason, we must be cautious in the interpretation of mildly elevated or low blood levels of $\mathrm{COHb}$ in children's charred corpses. Thus, the presence or absence of soot in the respiratory airways is of great importance as an indicator that the child was alive at the time of the fire. Remember that $\mathrm{COHb}$ saturation will not be "artificially elevated" in a dead person by being in or near a fire; soot will not enter the intact airways of a person already dead before the fire. On the other hand, one must consider that a person may have been alive during a fire, yet have normal $\mathrm{COHb}$ saturation levels in the blood - as described in flash fire victims. But is important to say that like any toxicology level the interpretation of $\mathrm{COHb}$ levels must be interpreted in the context of the entire case [4].

Thus the main objective of this research is to describe the necroscopic examination findings and the blood level of $\mathrm{COHb}$ in a sample of children charred corpses. This has real importance to the forensic practitioner because in his investigation of a scene of fire it can be crucial to identify if it was an accident or a potential crime.

\section{Methods}

We have conducted a retrospective and descriptive study by collecting information contained in the necroscopic reports of the Unity of Forensic Anthropology of Medico-Legal Institute of São Paulo State (IML). The data included 16 children under the age of 12 years who were victims of fires in a closed space from 2010 to 2017. All causes of death were signed as intoxication by Carbon Monoxide.

The collected data were grouped by year of occurrence, victims, presence of the Montalti sign, the concentration of $\mathrm{COHb}$, place of encounter of the corpse, and cause of death as recorded in the necropsy reports. Levels of $\mathrm{COHb}$ were determined in blood samples from 16 charred corpses that were autopsied between 2010 and 2017 in the toxicology laboratory of the Department of Legal Medicine, Faculty of Medicine, University of São Paulo. Percent of carboxyhemoglobin $(\% \mathrm{COHb})$ was determined by the micro-diffusion method [9]. All the victims were submitted to a complete $\mathrm{x}$-ray examination, before the necroscopic exam.

\section{Results}

Table 1 gathers the data collected from 16 child victims of fire, aged 12 years or under from 2010 to 2017. Of the 16 children, 10 (62.5\%) died with COHb concentrations below 50\% and 6 (37.5\%) had $\mathrm{COHb}$ concentrations greater than $50 \%$. The extent of the burns was less than or equal $30 \%$ of body surface area (BSA) in all victims $(100 \%)$. None of the victims presented any sign of fatal trauma. Signs of vitality, defined as either the presence of soot in the airways (Montalti sign)or detectable $\mathrm{COHb}$ in the blood were present in all sixteen victims. In absence of other plausible causes, all causes of death as stated in the necroscopic reports were $\mathrm{CO}$ poisoning.

\section{Discussion}

The forensic literature has established a percentage equal to
Table 1: Child Victims of Household Fires from 2010 to 2017 Examined at IML/SP.

\begin{tabular}{|c|c|c|c|c|}
\hline Year of event & Age & Montalti sign & $\mathrm{COHb}(\%)$ & Cause of death \\
\hline 2010 & None & - & - & - \\
\hline 2011 & 2 years & Present & $95 \%$ & $\begin{array}{c}\text { Intoxication by } \\
\text { CO }\end{array}$ \\
\hline 2011 & 3 years & Present & $41 \%$ & $\begin{array}{c}\text { Intoxication by } \\
\text { CO }\end{array}$ \\
\hline 2011 & 5 years & Present & $89 \%$ & $\begin{array}{c}\text { Intoxication by } \\
\text { CO }\end{array}$ \\
\hline 2012 & 1 years & Present & $21 \%$ & $\begin{array}{c}\text { Intoxication by } \\
\text { CO }\end{array}$ \\
\hline 2012 & 3 years & Present & $24 \%$ & $\begin{array}{c}\text { Intoxication by } \\
\text { CO }\end{array}$ \\
\hline 2012 & 5 years & Present & $17 \%$ & $\begin{array}{c}\text { Intoxication by } \\
\text { CO }\end{array}$ \\
\hline 2013 & 4 years & Present & $15 \%$ & $\begin{array}{c}\text { Intoxication by } \\
\text { CO }\end{array}$ \\
\hline 2013 & 5 years & Present & $27 \%$ & $\begin{array}{c}\text { Intoxication by } \\
\text { CO }\end{array}$ \\
\hline 2013 & 7 years & Present & $51 \%$ & $\begin{array}{c}\text { Intoxication by } \\
\text { CO }\end{array}$ \\
\hline 2014 & 1 year & Present & $61 \%$ & $\begin{array}{c}\text { Intoxication by } \\
\text { CO }\end{array}$ \\
\hline 2014 & 2 year & Present & $11 \%$ & $\begin{array}{c}\text { Intoxication by } \\
\text { CO }\end{array}$ \\
\hline 2014 & 6 years & Present & $75 \%$ & $\begin{array}{c}\text { Intoxication by } \\
\text { CO }\end{array}$ \\
\hline 2015 & 1 year & Present & $14 \%$ & $\begin{array}{l}\text { Intoxication by } \\
\text { CO }\end{array}$ \\
\hline 2015 & 4 years & Present & $11 \%$ & $\begin{array}{c}\text { Intoxication by } \\
\text { CO }\end{array}$ \\
\hline 2016 & 3 years & Present & $77 \%$ & $\begin{array}{c}\text { Intoxication by } \\
\text { CO }\end{array}$ \\
\hline $\begin{array}{l}2016 \\
2017 \\
2018 \\
2019 \\
2020 \\
2021\end{array}$ & $\begin{array}{c}12 \text { years } \\
\text { None } \\
\text { None } \\
\text { None } \\
\text { None } \\
\text { None }\end{array}$ & Present & $46 \%$ & $\begin{array}{c}\text { Intoxication by } \\
\text { CO }\end{array}$ \\
\hline
\end{tabular}

n $=16$ children, ages $\leq 12$ years. In 2010 and 2017 no children were examined

or greater than $50 \%$ of $\mathrm{COHb}$ in the blood as a lethal value $[5,7]$. However, this study reveals that more than half of deaths diagnosed with CO poisoning in our population (e.g., children aged below 12 years) occurred in victims with $\mathrm{COHb}$ concentrations below $50 \%$ - that is, in percentages lower than those described in the literature as a lethal dose for adults. In addition to the values found, it can be said that CO poisoning mortality in children can be present at lower concentrations than in adults since children present different physiologies, making them more sensitive to poisoning in lower concentrations in the closed environment. This can cause doubt when it comes to identifying the cause of death; in such cases, the presence of the Montalti sign is essential to confirm the cause of death $[5,7,10]$.

Is necessary to say that we don't investigate the presence of hydrogen cyanide in the blood of the children, which can be a confusion factor. As stated by Melez et al. [1], "the most important death mechanism in fire is smoke inhalation. Rapid death can occur due to carbon monoxide ( $\mathrm{CO}$ ) or hydrogen cyanide intoxication, or asphyxia due to the lack of oxygen in the air." Thus, the cause of deaths found in the reports (e.g., intoxication by $\mathrm{CO}$ ) could not be exact and it was chosen, probably, because was the only objective element the examiner had. 
Citation: Miziara ID, Miziara CSMG. Cause of Death in Carbonized Children: What is The Role of Carboxyhemoglobin? J Forensic Investigation. 2021; $9(1): 1$.

However, the analysis of these data serves to alert forensic pathologists of the importance of accurate necroscopic examination in carbonized children. In addition, future research must provide a greater amount of data on $\mathrm{COHb}$ levels in the blood of children to establish with certainty the lethal dose in these cases with minimum safety.

\section{Conclusion}

In a sample of 16 charred corpses of children, we found 10 of them with $\mathrm{COHb}$ blood level below $50 \%$ with no other cause of death detectable. This find suggests that the lethal level of $\mathrm{COHb}$ in children's blood is less than in adults. But further researches are necessary to clarify this important point in forensic medicine.

\section{References}

1. Melez IE, Arslan MN, Melez DO, Gürler AS, Büyüket $Y$ et al.(2017) Manner of Death Determination in Fire Fatalities - 5-year Autopsy Data of Istanbul City. Am J Forensic Med Pathol 38: 59-68.

2. Conway KS, Schmidt CJ, Brown TT (2020) Medical Examiner Review of FireRelated Homicides. Acad Forensic Pathol J 87-93.
3. Dolinak D, Matshes E, Lew E (2005) Environmental Injury, in, Forensic Pathology Principles and Practice. Elsevier Academic Press, Burlington.

4. Spitz WU (2006) Thermal Injuries, in Medicolegal Investigation of Death Charles C. Thomas Publisher Ltd, Springfield.

5. Saukko P, Knight B (2016) The Night's Forensic Pathology. Hodder Arnold, London.

6. Inácio DAS, Brandão BA "Forensic Toxicology: Carbon Monoxide Poisoning in Carbonized persons." Brazilian Journal of Forensic Sciences, Medical Law and Bioethics 5: 314-327.

7. Karapirli M, Kandemir E, Akyol S, Kantarci N, Kaya M et al. (2013) "Forensic and Clinical Carbon Monoxide (CO) Poisonings in Turkey: A Detailed Analysis." Journal of Forensic and Legal Medicine 20: 95-101.

8. Baselt RC, Cravey RH Disposition of Toxic Drugs and Chemical in Man, Year Book Medical Publishers, St. Louis.

9. Guatelli MA Intoxicacíon oxicarbonada, studio bioquímico y metodologia analítica. EUDEBA, Buenos Aires.

10. Ruas F, Mendonça MC, Real FC, Vieira DN, Teixeira HM (2014) "Carbon Monoxide Poisoning as a Cause of Death and Differential Diagnosis in the Forensic Practice: A Retrospective Study, 2000-2010." Journal of Forensic and Legal Medicine 24: 1-6. 